Article

\title{
Monoterpenoid Indole Alkaloids from Alstonia rupestris with Cytotoxic, Anti-Inflammatory and Antifungal Activities
}

\author{
Wei Wang ${ }^{1, \dagger}$, Ming-He Cheng ${ }^{2, \dagger}$ and Xiao-Hua Wang ${ }^{3, *}$
}

1 Department of Pharmacy, No. 455 Hospital of People's Liberation Army, Shanghai 200052, China

2 Department of Pharmacology, School of Pharmacy, Second Military Medical University, Shanghai 200433, China

3 Department of Pharmacy, No. 202 Hospital of People's Liberation Army, Shenyang 110003, Liaoning, China

$\dagger$ These authors contributed equally to this work.

* Author to whom correspondence should be addressed; E-Mail: syxhwang@163.com; Tel./Fax: +86-24-2885-3800.

Received: 22 April 2013; in revised form: 3 June 2013 / Accepted: 9 June 2013 /

Published: 21 June 2013

\begin{abstract}
Phytochemical investigation of the $70 \%$ EtOH extract of the leaves of Alstonia scholaris afforded seven new monoterpenoid indole alkaloids: scholarisins I-VII (1-7), and three known compounds: $(3 R, 5 S, 7 R, 15 R, 16 R, 19 E)$-scholarisine $\mathrm{F}$ (8), 3-epi-dihydrocorymine (9), and (E)-16-formyl-5 $\alpha$-methoxystrictamine (10). Structural elucidation of all the compounds was accomplished by spectral methods such as 1D- and 2D-NMR, IR, UV, and HRESIMS. The isolated compounds were tested in vitro for cytotoxicity against seven tumor cell lines, anti-inflammatory activities against Cox-1 and Cox-2, and antifungal potential against five species of fungi. Compounds 1, 6, and 10 exhibited significant cytotoxicities against all the tested tumor cell lines with $\mathrm{IC}_{50}$ values of less than $30 \mu \mathrm{M}$ and selective inhibition of Cox-2 comparable with the standard drug NS-398 (>90\%). Additionally, 1, 2, 3 and $\mathbf{8}$ showed antifungal activity against two fungal strains (G. pulicaris and C. nicotianae).
\end{abstract}

Keywords: Alstonia rupestris; Apocynaceae; monoterpenoid indole alkaloids; cytotoxicity; anti-inflammatory; antifungal 


\section{Introduction}

The genus Alstonia, which belongs to the family Apocynaceae, is widely distributed throughout the tropical areas of the World, including Central America, Africa, Indo-Malaya, Australia and Asia [1-3]. The genus Alstonia comprises about 60 species, eight of which grow in China [4]. Several of these species are used in Traditional Chinese Medicine, for example in the treatment of malaria, dysentery, defervescence, antitussive, and to arrest hemorrhages [5-10]. Monoterpenoid indole alkaloids occur abundantly in the family Apocynaceae [11-17], and to date, more than 300 such monoterpenoid indole alkaloids have been reported from the plants of this genus [18-22]. This type of alkaloids originates from the condensation of tryptophan with secologanin to give strictosidine and then further elaboration gives an impressive array of structural variants [23]. Monoterpenoid indole alkaloids were reported to have anticancer, antibacterial, antifertility, and anti-tussive activities [24-28]. Alstonia rupestris Kerr. is usually endemic in the western part of Guangxi Province of China. To the best of our knowledge, the phytochemistry of the A. rupestris has been rarely reported previously, which prompted the present study. Present investigation on chemical constituents of the EtOH extract of the leaves of $A$. rupestris led to seven new monoterpenoid indole alkaloids: scholarisin I-VII (1-7) together with three known compounds: $(3 R, 5 S, 7 R, 15 R, 16 R, 19 E)$-scholarisine F (8), 3-epi-dihydrocorymine (9), and (E)-16formyl-5 $\alpha$-methoxystrictamine (10) (Figure 1). The structures of these compounds were elucidated mainly by NMR spectroscopic and mass spectroscopic methods. Furthermore, all the alkaloids were in vitro evaluated for their cytotoxic, anti-inflammatory and antifungal activities.

Figure 1. The structures of compounds 1-10.
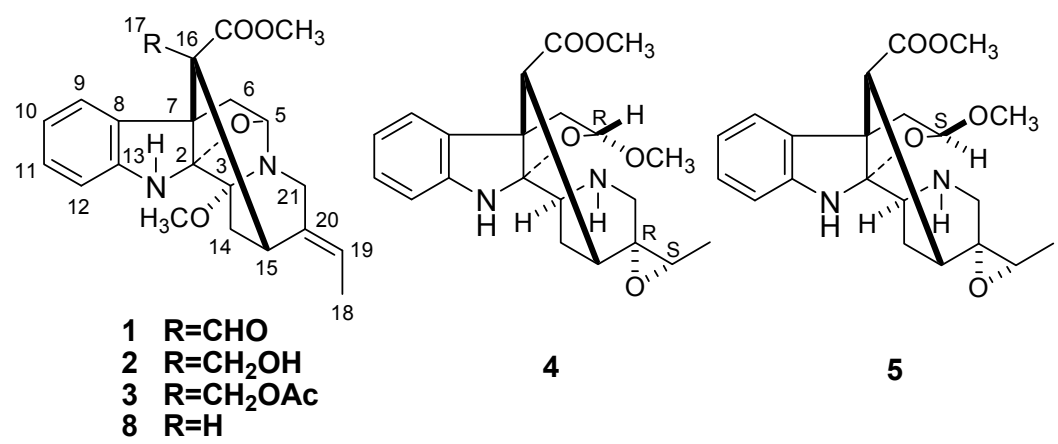

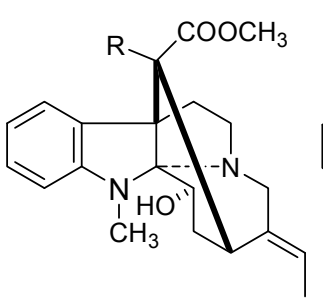

$6 \mathrm{R}=\mathrm{CHO}$

$9 \mathrm{R}=\mathrm{CH}_{2} \mathrm{OH}$

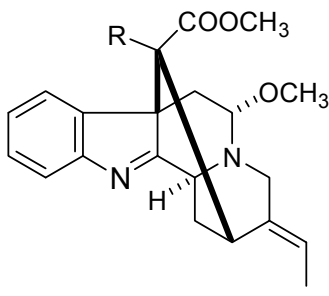

$7 \mathrm{R}=\mathrm{CH}_{2} \mathrm{OH}$ $10 \mathrm{R}=\mathrm{CHO}$

\section{Results and Discussion}

Compound 1 was obtained as a white amorphous powder. The positive HRESIMS spectrum displayed a pseudomolecular ion at $\mathrm{m} / z$ 419.1585 $[\mathrm{M}+\mathrm{Na}]^{+}$(calcd for $\mathrm{C}_{22} \mathrm{H}_{24} \mathrm{~N}_{2} \mathrm{O}_{5} \mathrm{Na}, 419.1583$ ) consistent with a molecular formula of $\mathrm{C}_{22} \mathrm{H}_{24} \mathrm{~N}_{2} \mathrm{O}_{5}$, corresponding to 12 degrees of unsaturation. Its UV characteristic absorption peaks at 285, 240, and $228 \mathrm{~nm}$ was for a indole chromophore. The IR spectrum exhibited absorptions at 3,425 and $1,725 \mathrm{~cm}^{-1}$ for $\mathrm{NH}$ and $\mathrm{C}=\mathrm{O}$ functions, respectively. Its ${ }^{13} \mathrm{C}-\mathrm{NMR}$ spectrum showed 22 carbon signals $\left[\mathrm{OCH}_{3} \times 2, \mathrm{CH}_{3} \times 1, \mathrm{CH}_{2}\left(\mathrm{sp}^{3}\right) \times 3, \mathrm{CH}\left(\mathrm{sp}^{3}\right) \times 2, \mathrm{C}\left(\mathrm{sp}^{3}\right) \times 4, \mathrm{CH}\right.$ $\left(\mathrm{sp}^{2}\right) \times 6$ and $\mathrm{C}\left(\mathrm{sp}^{2}\right) \times 4$, Table 1]. The ${ }^{1} \mathrm{H}-\mathrm{NMR}$ spectrum exhibited four aromatic proton signals $\left[\delta_{\mathrm{H}}\right.$ 7.31 and 6.68 (each, $1 \mathrm{H}, \mathrm{dd}, J=7.8,1.8 \mathrm{~Hz}$ ), 6.84 and 7.08 (each, $1 \mathrm{H}, \mathrm{dt}, J=7.8,1.8 \mathrm{~Hz}$ )] ascribed to an ortho-disubstituted benzene ring, an ethylidene side chain $[1.51$ (d, $J=7.0, \mathrm{H}-18)$ and 5.47 (q, $J=7.0$, $\mathrm{H}-19)$ ], a NH signal at $\delta_{\mathrm{H}} 4.96$, a downfield proton signal at $\delta_{\mathrm{H}} 8.52$ due to a formyl group and a singlet 
peak at $\delta_{\mathrm{H}} 3.50$ assigned to one methoxy group. The HMBCs of the proton signal at $\delta_{\mathrm{H}} 3.50\left(\mathrm{OCH}_{3}\right)$ with the carbon signals at $\delta_{C} 85.4(\mathrm{C}-3)$ indicated the methoxy group substitution at C-3. In the NOE spectrum, the correlation of the methoxy group at $\mathrm{C}-3$ with $\mathrm{H}-21 \alpha\left(\delta_{\mathrm{H}} 2.26\right)$ indicated the $\alpha$ orientation of the methoxy group (Figure 2). The NOE correlation of $\mathrm{H}-5 / \mathrm{H}-6 \beta$ and $\mathrm{H}-15 / \mathrm{H}-17$ evidenced the $\beta$ and $\alpha$ orientation of $\mathrm{H}-5$ and $\mathrm{H}-15$, respectively. The $E$-form of the double bond of 19/20 was determined on the basis of the NOE correlations of $\mathrm{H}-19 / 21$ and $\mathrm{H}-18 / 15$. These data suggested that the structure of 1 was almost identical with $(3 R, 5 S, 7 R, 15 R, 16 R, 17 R, 19 E)$-scholarisine $\mathrm{F}(\mathbf{8})$ [28]. The distinct difference was the presence of one more formyl group at $\mathrm{C}-16$ in $\mathbf{1}$, which was supported by the observation of the HMBC correlations of the proton signal at $\delta_{\mathrm{H}} 8.52(\mathrm{H}-17)$ with the carbon signals of $\mathrm{C}-7, \mathrm{C}-15$, and carbonyl group of carbomethoxy and the downfield chemical shift of C-16 from $\delta_{C} 51.5$ in 8 to $\delta_{C} 65.6$ in 1. Thus, 1 was named as scholarisin I and the structure was showed in Figure 1.

Table 1. ${ }^{13} \mathrm{C}-\mathrm{NMR}$ data of compounds $\mathbf{1}-\mathbf{7}$ in $\mathrm{CDCl}_{3}$.

\begin{tabular}{cccccccc}
\hline No. & $\mathbf{1}$ & $\mathbf{2}$ & $\mathbf{3}$ & $\mathbf{4}$ & $\mathbf{5}$ & $\mathbf{6}$ & $\mathbf{7}$ \\
\hline 2 & 107.5 & 105.6 & 107.0 & 103.5 & 104.9 & 102.0 & 186.7 \\
3 & 85.4 & 85.1 & 85.3 & 51.9 & 51.1 & 70.6 & 50.8 \\
5 & 86.1 & 85.6 & 85.9 & 105.4 & 106.9 & 63.5 & 89.7 \\
6 & 42.5 & 44.4 & 42.9 & 42.8 & 40.9 & 42.5 & 43.6 \\
7 & 55.1 & 53.1 & 55.5 & 52.3 & 52.4 & 62.4 & 53.2 \\
8 & 131.5 & 131.6 & 133.1 & 138.0 & 136.8 & 131.3 & 142.4 \\
9 & 126.0 & 126.0 & 126.1 & 122.7 & 123.4 & 121.6 & 121.6 \\
10 & 121.5 & 122.1 & 121.9 & 119.9 & 120.0 & 127.5 & 124.9 \\
11 & 128.9 & 128.6 & 128.9 & 128.1 & 128.5 & 130.6 & 125.4 \\
12 & 110.7 & 110.4 & 110.3 & 109.1 & 110.2 & 112.5 & 120.8 \\
13 & 147.9 & 148.3 & 147.8 & 144.6 & 145.9 & 148.7 & 156.1 \\
14 & 25.0 & 28.5 & 23.6 & 26.2 & 27.0 & 34.2 & 35.8 \\
15 & 34.1 & 33.5 & 37.3 & 27.7 & 28.3 & 34.2 & 33.4 \\
16 & 65.6 & 54.4 & 55.0 & 52.8 & 52.1 & 65.6 & 58.8 \\
17 & 197.4 & 65.9 & 66.2 & - & - & 194.5 & 63.0 \\
18 & 13.4 & 13.7 & 13.6 & 12.8 & 12.9 & 15.1 & 13.5 \\
19 & 120.7 & 119.7 & 119.8 & 58.4 & 58.5 & 133.2 & 127.8 \\
20 & 130.5 & 131.3 & 131.3 & 61.5 & 61.6 & 129.9 & 137.7 \\
21 & 47.9 & 48.1 & 48.2 & 44.7 & 44.5 & 66.6 & 50.5 \\
$\mathrm{CO}_{2} \mathrm{CH}_{3}$ & 168.0 & 169.3 & 169.4 & 172.1 & 172.6 & 171.9 & 169.1 \\
$\mathrm{CO}_{2} \mathrm{CH}_{3}$ & 52.7 & 51.5 & 51.7 & 51.8 & 51.6 & 53.9 & 51.4 \\
$N_{1}-\mathrm{CH}_{3}$ & - & - & - & - & - & 50.5 & - \\
$\mathrm{OCH}_{3}$ & 48.6 & 48.5 & 48.4 & 54.8 & 57.0 & - & 54.7 \\
$\mathrm{COCH}_{3}$ & - & - & 171.3 & - & - & - & - \\
$\mathrm{COCH}_{3}$ & - & - & 20.1 & - & - & - & - \\
\hline & & & & & & &
\end{tabular}

Compound 2 was isolated as a white amorphous powder. Its positive HRESIMS spectrum showed a quasimolecular ion peak at $m / z 399.1924[\mathrm{M}+\mathrm{H}]^{+}$, consistent with the molecular formula $\mathrm{C}_{22} \mathrm{H}_{26} \mathrm{~N}_{2} \mathrm{O}_{5}$. Comparing the ${ }^{1} \mathrm{H}$ - and ${ }^{13} \mathrm{C}-\mathrm{NMR}$ data of 2 with those of compound $\mathbf{1}$, the data were almost identical. The only significant difference was that the formyl group at C-16 was replaced by a hydroxymethyl group in compound 2, which was confirmed by the HMBC correlations of the proton signal of the 
hydroxymethyl group $\left[\delta_{\mathrm{H}} 3.22,3.46\right.$ (each, $\left.\left.1 \mathrm{H}, \mathrm{d}, J=13.8\right)\right]$ with the carbonyl group of carbomethoxy at $\delta_{C}$ 169.3. On the basis of the observation of NOESY data similar to those of $\mathbf{1}$, the stereochemistry of $\mathbf{2}$ was expected to be the same. Accordingly, the structure of 2 was established as scholarisin II and the structure was showed in Figure 1.

Figure 2. Key HMBC $(\frown)$ and NOESY $(\curvearrowleft)$ correlations of of compound $\mathbf{1}$.
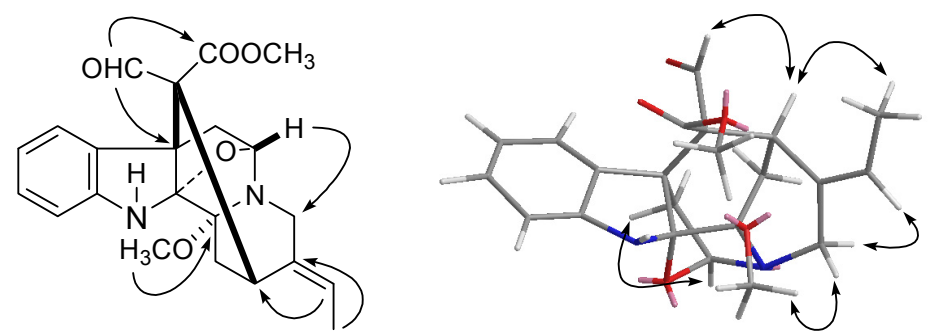

Compound 3 was obtained as a white amorphous powder. The EIMS afforded a molecular weight of $m / z 440$, and its HRESIMS revealed the $[\mathrm{M}+\mathrm{H}]^{+}$peak at $m / z 441.2025$ (calcd. for $\mathrm{C}_{24} \mathrm{H}_{29} \mathrm{~N}_{2} \mathrm{O}_{6}$. 441.2026), corresponding to the molecular formula $\mathrm{C}_{24} \mathrm{H}_{28} \mathrm{~N}_{2} \mathrm{O}_{6}$. The general features of its IR and NMR spectra closely resembled those of $\mathbf{2}$, except for the presence of one more Ac group. The OAc group were positioned at $\mathrm{C}-17$ based on HMBC correlations of $\mathrm{H}-17$ [ $\delta 3.87$ and 4.01 (each, 1H, d, $J=13.8$ )] with the acyl carbon ( $\delta 171.3$ ) of the acetyl group. The stereochemistry of $\mathbf{3}$ was expected to be the same as $\mathbf{2}$ on the basis of the NOESY data. Thus, compound $\mathbf{3}$ was elucidated as scholarisin III and the structure was as shown in Figure 1.

Compound 4, a white amorphous powder, gave one quasimolecular ion peak at $\mathrm{m} / \mathrm{z} 409.1735$ $[\mathrm{M}+\mathrm{Na}]^{+}$in its HRESIMS, accounting for a molecular formula of $\mathrm{C}_{21} \mathrm{H}_{26} \mathrm{~N}_{2} \mathrm{O}_{5}$. The IR spectrum showed absorption peaks at $3430(\mathrm{NH})$ and $1740(\mathrm{C}=\mathrm{O}) \mathrm{cm}^{-1}$. In the ${ }^{1} \mathrm{H}-\mathrm{NMR}$ spectrum, four aromatic proton signals at $\delta_{\mathrm{H}} 7.12$ and 6.56 (each, $1 \mathrm{H}, \mathrm{dd}, J=8.2,1.8 \mathrm{~Hz}$ ), 6.78 and 7.06 (each, $1 \mathrm{H}, \mathrm{dt}, J=8.2,1.8 \mathrm{~Hz}$ )] showed an ortho-disubstituted benzene ring, two singlet peaks at $\delta_{\mathrm{H}} 3.10$ and 3.70 were assigned to the protons of a methoxy and a carbomethoxy group, respectively. Its ${ }^{13} \mathrm{C}$-NMR displayed a pattern similar to that of scholarisine $\mathrm{C}$ [28], except that the double bond of 19/20 was substituted by a methine at $\delta_{C}$ 58.4 (d, C-19) and a quaternary carbon at $\delta_{C} 61.5$ (s, C-20). The molecular formula $\mathrm{C}_{21} \mathrm{H}_{26} \mathrm{~N}_{2} \mathrm{O}_{5}$ displayed 10 unsaturation degrees, which indicated the presence of 19,20-epoxide combined with the appropriate NMR data. The NOE correlation of $\mathrm{H}-3 / \mathrm{H}-14 \alpha$ indicated the $\alpha$ configuration of C-3 (Figure $3)$. On the basis of the NOE correlations of H-15/H-19 and H-18/21, the configurations of C-19 and C-20 was elucidated as $S$ and $R$, respectively. The $R$ configuration of C-5 was determined by the coupling constant of H-5 (d, $J=5.2 \mathrm{~Hz})$ compared with that of scholarisine C $(\mathrm{d}, J=5.4 \mathrm{~Hz})$ [28]. Therefore, compound $\mathbf{4}$ was determined as scholarisin IV, with the structure as shown in Figure 1.

Compound 5, a white amorphous powder, exhibited a molecular formula of $\mathrm{C}_{21} \mathrm{H}_{26} \mathrm{~N}_{2} \mathrm{O}_{5}$, based on the HRESIMS spectrum which showed a pseudomolecular ion at $\mathrm{m} / z 387.1923[\mathrm{M}+\mathrm{H}]^{+}$(calcd. 387.1920). The general features of NMR spectra closely resembled those of 4 , except for the configuration of C-5. H-5 was observed as a doublet of doublets at $\delta_{\mathrm{H}} 4.90(1 \mathrm{H}, \mathrm{dd}, J=7.2,5.6 \mathrm{~Hz}) \mathrm{in}$ the ${ }^{1} \mathrm{H}-\mathrm{NMR}$ spectrum, which indicated the $S$ configuration of C-5 [28]. This evidence indicated that compound $\mathbf{5}$ was an isomer of $\mathbf{4}$, and $\mathbf{5}$ was identified as scholarisin $\mathrm{V}$, with the structure shown in Figure 1. 
Figure 3. Key HMBC $(\frown)$ ) and NOESY $(\curvearrowleft)$ correlations of of compound 4 .
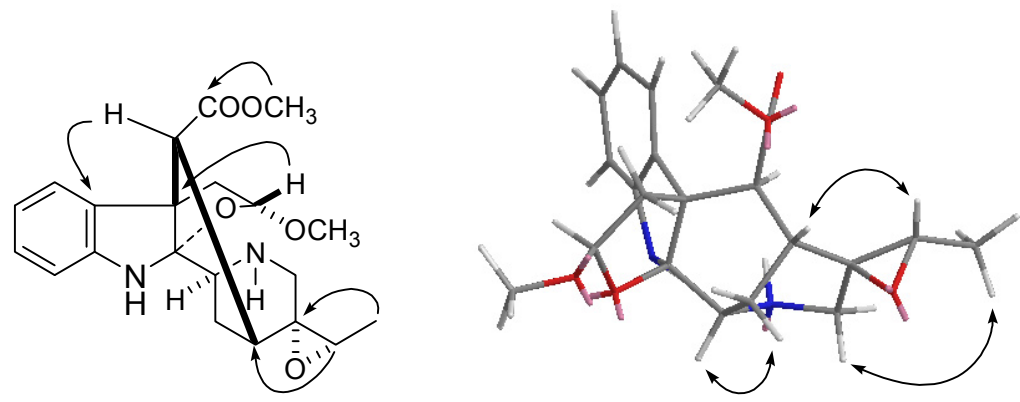

Compound 6, a white amorphous powder, exhibited a molecular formula of $\mathrm{C}_{22} \mathrm{H}_{26} \mathrm{~N}_{2} \mathrm{O}_{4}$, based on the HRESIMS spectrum which showed a pseudomolecular ion at $\mathrm{m} / z 383.1974[\mathrm{M}+\mathrm{H}]^{+}$(calcd. 383.1971). The UV absorptions at 286, 241 and $220 \mathrm{~nm}$ showed the presence of an indole chromophore. The IR spectrum indicated the presence of formyl group $\left(1720 \mathrm{~cm}^{-1}\right)$, and benzene ring $\left(1650 \mathrm{~cm}^{-1}\right)$. Its ${ }^{13} \mathrm{C}-\mathrm{NMR}$ spectrum showed 22 carbon signals $\left[\mathrm{CH}_{3} \times 2, \mathrm{OCH}_{3} \times 1, \mathrm{CH}_{2}\left(\mathrm{sp}^{3}\right) \times 4, \mathrm{CH}\right.$ $\left(\mathrm{sp}^{3}\right) \times 3, \mathrm{C}\left(\mathrm{sp}^{3}\right) \times 2, \mathrm{CH}\left(\mathrm{sp}^{2}\right) \times 6$ and $\mathrm{C}\left(\mathrm{sp}^{2}\right) \times 4$, Table 1]. The ${ }^{1} \mathrm{H}-\mathrm{NMR}$ spectrum exhibited four ortho-disubstituted aromatic proton signals $\left[\delta_{\mathrm{H}} 7.76\right.$ and 6.79 (each, $1 \mathrm{H}, \mathrm{dd}, J=7.8,2.0 \mathrm{~Hz}$ ), 6.92 and 7.24 (each, $1 \mathrm{H}, \mathrm{dt}, J=7.8,2.0 \mathrm{~Hz}$ )], an ethylidene side chain [1.83 (d, $J=7.2, \mathrm{H}-18)$ and $5.86(\mathrm{q}, J=7.2$, $\mathrm{H}-19)]$, a $N-\mathrm{CH}_{3}\left(\delta_{\mathrm{H}} 2.03\right)$, a formyl group $\left(\delta_{\mathrm{H}} 8.55\right)$, one methoxy group $\left(\delta_{\mathrm{H}} 3.80\right)$. These data showed similarities to those of 3-epi-dihydrocorymine (9) [29]. Comparing the ${ }^{1} \mathrm{H}$ - and ${ }^{13} \mathrm{C}$-NMR data of 6 with those of 3-epi-dihydrocorymine, the data were almost identical. The only significant difference was that the signals of one hydroxymethyl group was replaced by those of the formyl group $\left(\delta_{\mathrm{C}} 194.5 ; \delta_{\mathrm{H}} 8.55\right)$, which was supported by the observation of the $\mathrm{HMBC}$ correlations of the proton signal at $\delta_{\mathrm{H}} 8.55(\mathrm{H}-17)$ with the carbon signals of C-7, C-15 and carbonyl group of carbomethoxy (Figure 4). In the NOE experiment, the correlation of $\mathrm{H}-3 / \mathrm{H}-21 \beta$ indicated the $\beta$ orientation of $\mathrm{C}-3$. The $E$-form of the double bond of $19 / 20$ was determined on the basis of the NOE correlations of H-19/21 and H-18/15. On the basis of the observation of NOESY data similar to those of $\mathbf{9}$, the stereochemistry of $\mathbf{6}$ was expected to be the same. Accordingly, the structure of $\mathbf{6}$ was established as scholarisin VI (Figure 1).

Figure 4. Key HMBC $(\frown)$ ) and NOESY $(\curvearrowleft)$ correlations of of compound 6 .
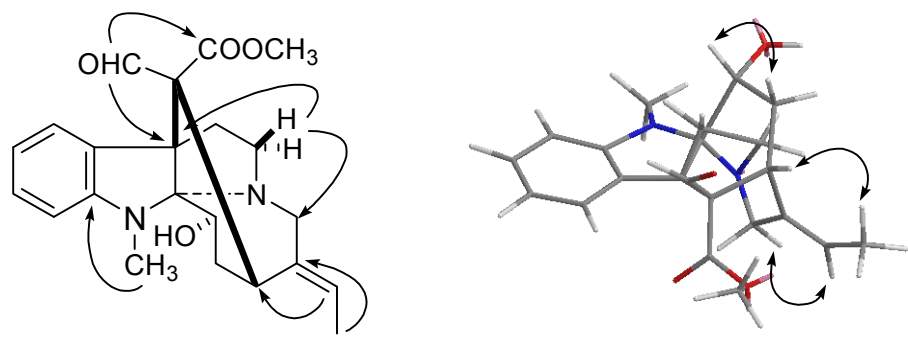

The molecular formula of compound 7 was assigned as $\mathrm{C}_{22} \mathrm{H}_{26} \mathrm{~N}_{2} \mathrm{O}_{4}$ on the basis of the quasimolecular ion peak $[\mathrm{M}+\mathrm{Na}]^{+}$at $\mathrm{m} / z 405.1787$ in the HRESIMS. The ${ }^{13} \mathrm{C}-\mathrm{NMR}$ and DEPT spectra displayed signals of three $\mathrm{Me}$, four $\mathrm{CH}_{2}$, and nine $\mathrm{CH}$ groups, together with six quaternary $\mathrm{C}$-atoms. The NMR signals at $\delta_{\mathrm{H}} 7.79(\mathrm{dd}, J=8.0,2.0 \mathrm{~Hz}, \mathrm{H}-9), 7.32$ (dt, $\left.J=8.0,2.0 \mathrm{~Hz}, \mathrm{H}-10\right), 7.14$ (dt, $J=8.0,2.0$ $\mathrm{Hz}, \mathrm{H}-11), 7.39$ (dd, $, J=8.0,2.0 \mathrm{~Hz}, \mathrm{H}-12)$, and those at $\delta_{\mathrm{C}} 142.4$ (C-8), 121.6 (C-9), 124.9 (C-10), 
125.4 (C-11) , 120.8 (C-12), and 156.1 (C-13) were characteristic for the presence of an indole moiety. The NMR data of 7 was almost identical with those of $(E)$-16-formyl-5 $\alpha$-methoxystrictamine (10) [30]. The only significant difference was that a hydroxymethyl group $\left[\delta_{\mathrm{H}} 3.68,3.91\right.$ (each, $1 \mathrm{H}, \mathrm{d}, J=13.2$ ) $]$ in 7 instead of the formyl group at C-16 in 10, was confirmed by HMBC correlations of H-17 with C-7, $\mathrm{C}-15$ and carbonyl group of carbomethoxy (Figure 5). The relative configuration of compound 7 was determined by the NOESY experiment. Based on the similarity of NOE spectrum with that of 10, the NOE interactions of $\mathrm{H}-3 / \mathrm{H}-14 \alpha, \mathrm{H}-15 / \mathrm{H}-14 \alpha, \mathrm{H}-5 / \mathrm{H}-21$, and $\mathrm{H}-15 / \mathrm{H}-18$ indicated the $\mathrm{H}-3 \alpha, \mathrm{H}-15 \alpha$, and $19 E$ configuration compared with that of $(E)$-16-formyl-5 $\alpha$-methoxystrictamine. From these data, 7 was named scholarisin VII.

Figure 5. Key HMBC $(\frown)$ and NOESY $(\curvearrowleft)$ correlations of of compound 7.
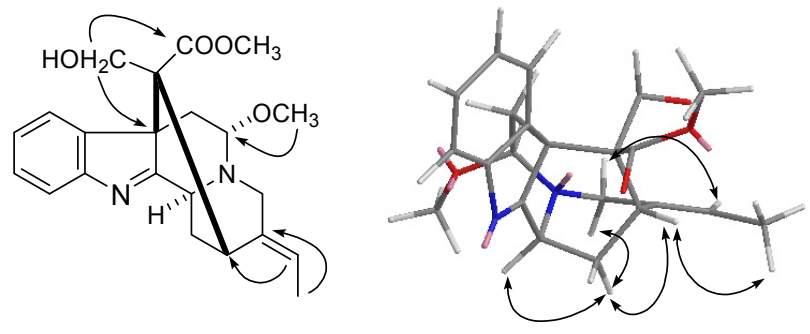

The in vitro cytotoxic activities of the isolated alkaloids were evaluated against seven tumor cell lines by using the revised MTT method as described in the Experimental. The results are summarized in Table 2. Alkaloids $\mathbf{1 , 6}$, and $\mathbf{1 0}$ exhibited significant cytotoxicity $\left(\mathrm{IC}_{50}<30 \mu \mathrm{M}\right)$ while $\mathbf{2 , 3}$, and $\mathbf{7 - 9}$ showed weak cytotoxic activites $\left(\mathrm{IC}_{50}>40 \mu \mathrm{M}\right)$ against all the tested tumor cell lines. Furthermore, alkaloids 4 and 5 without the linkage between C-5 and N-4 were non-cytotoxic $\left(\mathrm{IC}_{50}>80 \mu \mathrm{M}\right)$. The results indicated that the linkage between $\mathrm{C}-5$ and N-4 was essential for cytotoxic properties, while the formyl group on C-16 might strengthen the cytotoxic activities for this type of alkaloids.

Table 2. Cytotoxicity of compounds $\mathbf{1}-\mathbf{1 0}$ against seven human tumor cell lines $\left(\mathrm{IC}_{50}, \mu \mathrm{M}\right)^{\mathrm{a}}$.

\begin{tabular}{cccccccc}
\hline Compound & \multicolumn{7}{c}{ Cell lines } \\
\hline $\mathbf{1}$ & A-549 & BGC-823 & HepG2 & HL-60 & MCF-7 & SMMC-7721 & W480 \\
$\mathbf{2}$ & 10.3 & 11.3 & 9.2 & 12.0 & 10.7 & 23.7 & 28.0 \\
$\mathbf{3}$ & 52.7 & 61.8 & 49.0 & 59.4 & 54.3 & 59.7 & 59.5 \\
$\mathbf{4}$ & 44.1 & 40.8 & 30.4 & 39.6 & 36.8 & 47.0 & 40.1 \\
$\mathbf{5}$ & - & - & - & - & - & - & 94.9 \\
$\mathbf{6}$ & 97.4 & - & - & - & - & 92.1 & - \\
$\mathbf{7}$ & 13.0 & 12.9 & 10.8 & 12.3 & 11.3 & 24.9 & 29.9 \\
$\mathbf{8}$ & 49.1 & 53.2 & 43.6 & 48.2 & 46.7 & 49.4 & 52.7 \\
$\mathbf{9}$ & 47.8 & 51.5 & 44.8 & 50.7 & 48.9 & 53.2 & 51.4 \\
$\mathbf{1 0}$ & 61.3 & 67.1 & 58.3 & 71.8 & 64.2 & 66.2 & 62.1 \\
Doxorubicin & 16.1 & 15.7 & 14.8 & 17.2 & 14.7 & 31.2 & 35.5 \\
\hline
\end{tabular}

${ }^{\mathrm{a}}$ Doxorubicin activities are expressed as $\mathrm{IC}_{50}$ values in $\mathrm{nM}$, and those of compounds $\mathbf{1}-\mathbf{8}$ are expressed as $\mathrm{IC}_{50}$ values in $\mu \mathrm{M}$. (-) $\mathrm{IC}_{50}>100 \mu \mathrm{M}$. 
The compounds 1-10 were tested in vitro for their anti-inflammatory activities. The results of the anti-inflammatory assay were summarized in Table 3. Among the assayed compounds, only alkaloids $\mathbf{1}$, $\mathbf{6}$ and $\mathbf{1 0}$ with formyl group at C-16 displayed selective inhibition of Cox-2 (>90\%). Alkaloids 2-5 and 7-9 had no anti-inflammatory activities or selective inhibition of Cox-2 comparable to those of $\mathbf{1}, \mathbf{6}$ and 10 although they possess the same monoterpene indole skeleton. The observations indicated that the formyl group at C-16 should be essential for this type of alkaloids to possess the anti-inflammatory activity.

Table 3. Evaluation of Anti-Inflammatory Activity of Compounds $\mathbf{1 - 1 0}{ }^{\mathrm{a}}$.

\begin{tabular}{ccc}
\hline Compound & COX-1 & COX-2 \\
\hline $\mathbf{1}$ & 45.2 & 96.4 \\
$\mathbf{2}$ & $<0$ & 14.9 \\
$\mathbf{3}$ & 12.9 & 50.4 \\
$\mathbf{4}$ & $<0$ & 21.1 \\
$\mathbf{5}$ & $<0$ & 24.3 \\
$\mathbf{6}$ & 36.9 & 95.5 \\
$\mathbf{7}$ & $<0$ & 17.6 \\
$\mathbf{8}$ & $<0$ & $<0$ \\
$\mathbf{9}$ & 13.6 & 46.8 \\
$\mathbf{1 0}$ & 38.5 & 92.0 \\
SC-560 & 63.2 & \\
NS-398 & & 97.1 \\
\hline inhibition (all compounds and reference drugs concentration: $100 \mu \mathrm{M})$.
\end{tabular}

All compounds were tested for their antifungal activities by the disc diffusion method by measuring the inhibition zones and for the most active compounds, minimum inhibitory concentration (MIC) values were also determined. Antifungal properties (Table 4) showed that alkaloids 1, 2, 3 and 8 exhibited antifungal activity against two fungi ( $G$. pulicaris and $C$. nicotianae), with MIC values of 0.64-0.69 mM, 1.37-1.44 mM, 1.80-1.91 mM and 1.55-1.71 mM, respectively. Alkaloids 1 possessed rather higher antifungal potent with lower MIC value. The other alkaloids had no a antifungal activities. These result suggested that the structure skeleton of 1 may be essential and the $N$-carbamate group could strengthen the antifungal activities of this type of alkaloids.

Table 4. Antifungal activities (zones of inhibition/and MIC mM, $\mathrm{n}=3$ ) of compounds 1-10.

\begin{tabular}{|c|c|c|c|c|c|}
\hline Compound & G. pulicaris & A. alternata & C. nicotianae & P. capsici. & G. amomi \\
\hline 1 & $20 / 0.69$ & - & $19 / 0.64$ & - & - \\
\hline 2 & $18 / 1.37$ & - & $17 / 1.44$ & - & - \\
\hline 3 & $15 / 1.91$ & - & $16 / 1.80$ & - & - \\
\hline 4 & - & - & - & - & - \\
\hline 5 & - & - & - & - & - \\
\hline 6 & - & - & - & - & - \\
\hline 7 & - & - & - & - & - \\
\hline 8 & $15 / 1.71$ & - & $17 / 1.55$ & - & - \\
\hline 9 & - & - & - & - & - \\
\hline 10 & - & - & - & - & - \\
\hline Nystatin & $21 / 0.007$ & $19 / 0.006$ & $19 / 0.006$ & $20 / 0.010$ & $19 / 0.009$ \\
\hline
\end{tabular}




\section{Experimental}

\subsection{General}

Optical rotations were determined with a JASCO P2000 digital polarimeter (Tokyo, Japan). Ultraviolet (UV) and infrared (IR) spectra were obtained on JASCO V-650 and JASCO FT/IR-4100 spectrophotometers (Tokyo, Japan), respectively. NMR spectra were measured on a Bruker AM-600 spectrometer $\left({ }^{1} \mathrm{H}-\mathrm{NMR}\right)$ and Bruker AM-400 spectrometer $\left({ }^{13} \mathrm{C}-\mathrm{NMR}\right)$. EIMS and HREIMS $(70 \mathrm{eV})$ were carried out on a Finnigan MAT 95 mass spectrometer. All solvents used were of analytical grade (Shanghai Chemical Reagents Company Ltd., Shanghai, China). Silica gel (200-300 mesh), silica gel H (Qingdao Haiyang Chemical Co. Ltd., Qingdao, China), C18 reversed-phase silica gel (150-200 mesh, Merck), and MCI gel (CHP20P, 75-150 lm, Mitsubishi Chemical Industries Ltd., Tokyo, Japan) were used for column chromatography. HPLC separation was performed on an instrument consisting of a Waters 600 controller, a Waters 600 pump, and a Waters 2487 dual $\lambda$ absorbance detector, with a Prevail $(250 \times 10 \mathrm{~mm}$ i.d.) preparative column packed with $\mathrm{C} 18$ silica $(5 \mu \mathrm{m})$.

\subsection{Plant Material}

The leaves of A. scholaris were collected in Yongning, Guangxi Province, China, in September 2011. The sample was identified by one of the authors (G. B. Shi). A specimen (201109001AS) was deposited in the Herbarium of Shengyang Medicine College, Shengyang, China.

\subsection{Extraction and Isolation}

The dried leaves of $A$. scholaris $(16 \mathrm{~kg})$ were powdered and extracted thrice with $70 \%$ ethanol $(25 \mathrm{~L})$ at room temperature and then concentrated under reduced pressure to give a crude extract (198.5 g). The crude extract was partitioned between equal volumes of ethyl acetate and water to provide an EtOAc-soluble (77.5 g) and an aqueous layer. The EtOAc-soluble fraction was subjected to silica gel column chromatography eluted with $\mathrm{CHCl}_{3} / \mathrm{MeOH}$ (from 100:1 to 1:1) to yield seven fractions (F1-F7).

F2 (4.3 g) was further subjected to silica gel column chromatography eluted with $\mathrm{CHCl}_{3} / \mathrm{MeOH}$ (from 10:1 to 1:1) to give three subfractions F2a (276 mg), F2b (253 mg), and F2c (226 mg). Subfraction F2a was separated by repeated column chromatography over Sephadex LH-20 $\left(\mathrm{CHCl}_{3} / \mathrm{MeOH}, 1: 1\right.$, and $\mathrm{MeOH})$, then puried on silica gel column chromatography eluted with n-hexane/EtOAc (7:3) to yield $\mathbf{8}$ (99.1 mg). Subfraction F2b was further subjected to reverse phase high performance liquid chromatography (RP-HPLC) eluted with methanol/water (70:30) to furnish compounds 4 (56.1 mg) and $5(56.1 \mathrm{mg})$. F2c was subjected to a normal phase high performance liquid chromatography (NP-HPLC) eluted with n-hexane/ethyl acetate (8:1) to afford compound $\mathbf{3}(65.3 \mathrm{mg})$ and $\mathbf{1}(64.3 \mathrm{mg})$. F3 (4.9 g) was subjected to a silica gel column chromatography eluted with n-hexane/EtOAc (from $100 \%$ n-hexane to $100 \%$ EtOAc) to furnish four subfractions (F3a-F3d). F3b (588 mg) was separated on a reverse-phase HPLC eluted with methanol/water (65:35) to yield three compounds $2(59.3 \mathrm{mg})$ and $\mathbf{1 0}(49.5 \mathrm{mg}) . \mathrm{F} 3 \mathrm{c}$ (406 mg) was chromatographed on a reverse phase HPLC column eluted with methanol/water (55:45) to yield 7 (78.9 mg). F4 (2.3 g) was separated using a silica gel column and eluted with $n$-hexane/ $\mathrm{CH}_{2} \mathrm{Cl}_{2} / \mathrm{MeOH}(30: 70: 1.5)$ to give two subfractions $\mathrm{F} 4 \mathrm{a}(380 \mathrm{mg}$ ) and $\mathrm{F} 4 \mathrm{~b}$ (260 mg). F4a was further 
subjected to a reverse phase HPLC column eluted with methanol/water (65:35) to provide two compounds 6 (69.3 mg) and $9(49.5 \mathrm{mg})$.

Scholarisin I (1). White amorphous powder. $[\alpha]_{D}^{23.3}:-38.8(c=0.80, \mathrm{MeOH}) . \mathrm{UV}\left(\mathrm{CHCl}_{3}\right) \lambda_{\max }(\log \varepsilon)$ 285 (2.81), 240 (3.40), 228 (2.83) nm. IR (KBr) $v_{\max } 3425,1725,1465,1175,1090,1062,870,753 \mathrm{~cm}^{-1}$. ${ }^{1} \mathrm{H}-\mathrm{NMR}\left(\mathrm{CDCl}_{3}, 600 \mathrm{MHz}\right)$ and ${ }^{13} \mathrm{C}-\mathrm{NMR}\left(\mathrm{CDCl}_{3}, 125 \mathrm{MHz}\right)$ data see Table 5 and Table 1 respectively. EI-MS m/z: $396\left([\mathrm{M}]^{+}\right)$. HRESIMS (pos.) $\mathrm{m} / z$ : $419.1585\left([\mathrm{M}+\mathrm{Na}]^{+}, \mathrm{C}_{22} \mathrm{H}_{24} \mathrm{~N}_{2} \mathrm{O}_{5} \mathrm{Na}\right.$. calc. 419.1583).

Scholarisin II (2). White amorphous powder. $[\alpha]_{D}^{23.3}:-30.9(c=0.62, \mathrm{MeOH})$. UV $\left(\mathrm{CHCl}_{3}\right) \lambda_{\max }(\log \varepsilon)$ 286 (2.85), 240 (3.46), 228 (2.78), 228 (2.82) nm. IR (KBr) $v_{\max }$ 3445, 3420, 1730, 1464, 1170, 1065, $875 \mathrm{~cm}^{-1} .{ }^{1} \mathrm{H}-\mathrm{NMR}\left(\mathrm{CDCl}_{3}, 600 \mathrm{MHz}\right)$ and ${ }^{13} \mathrm{C}-\mathrm{NMR}\left(\mathrm{CDCl}_{3}, 125 \mathrm{MHz}\right)$ data see Table 5 and Table 1 respectively. EI-MS m/z: $398\left([\mathrm{M}]^{+}\right.$). HRESIMS (pos.) $m / z$ : calc. $399.1924[\mathrm{M}+\mathrm{H}]^{+}, \mathrm{C}_{22} \mathrm{H}_{27} \mathrm{~N}_{2} \mathrm{O}_{5}$. calc. 399.1920).

Scholarisin III (3). White amorphous powder. $[\alpha]_{D}^{23.3}:-35.4(c=0.76, \mathrm{MeOH}) . \mathrm{UV}\left(\mathrm{CHCl}_{3}\right) \lambda_{\max }(\log \varepsilon)$ 286 (2.80), 242 (3.30), 227 (2.89) nm. IR (KBr) $v_{\max } 3425,1735,1460,1172,1092,1062,871 \mathrm{~cm}^{-1}$. ${ }^{1} \mathrm{H}-\mathrm{NMR}\left(\mathrm{CDCl}_{3}, 600 \mathrm{MHz}\right)$ and ${ }^{13} \mathrm{C}-\mathrm{NMR}\left(\mathrm{CDCl}_{3}, 125 \mathrm{MHz}\right)$ data see Table 5 and Table 1 respectively. EI-MS m/z: $440\left([\mathrm{M}]^{+}\right)$. HRESIMS (pos.) $m / z: 441.2025\left([\mathrm{M}+\mathrm{H}]^{+}, \mathrm{C}_{24} \mathrm{H}_{29} \mathrm{~N}_{2} \mathrm{O}_{6}\right.$. calc. 441.2026).

Scholarisin IV (4). White amorphous powder. $[\alpha]_{D}^{23.3}:-38.2(c=0.30, \mathrm{MeOH}) . \mathrm{UV}\left(\mathrm{CHCl}_{3}\right) \lambda_{\max }(\log \varepsilon)$ 284 (3.45), 241 (3.62), 220 (3.32) nm. IR (KBr) $v_{\max }$ 3430, 2950, 1740, 1628, 1465, 1102, $750 \mathrm{~cm}^{-1}$. ${ }^{1} \mathrm{H}-\mathrm{NMR}\left(\mathrm{CDCl}_{3}, 600 \mathrm{MHz}\right)$ and ${ }^{13} \mathrm{C}-\mathrm{NMR}\left(\mathrm{CDCl}_{3}, 125 \mathrm{MHz}\right)$ data see Table 5 and Table 1 respectively. EI-MS: $386\left([\mathrm{M}]^{+}\right)$. HRESIMS (pos.) $m / z$ : $409.1735\left([\mathrm{M}+\mathrm{Na}]^{+}, \mathrm{C}_{21} \mathrm{H}_{26} \mathrm{~N}_{2} \mathrm{O}_{5} \mathrm{Na}\right.$. calc. 409.1739).

Scholarisin $V(5)$. White amorphous powder. $[\alpha]_{D}^{23.3}:-18.5(c=0.23, \mathrm{MeOH})$. UV $\left(\mathrm{CHCl}_{3}\right) \lambda_{\max }(\log \varepsilon)$ 285 (3.15), 240 (3.68), 228 (3.01) nm. IR (KBr) $v_{\max }$ 3423, 1735, 1635, 1465, 1447, 1170, $1035 \mathrm{~cm}^{-1}$. ${ }^{1} \mathrm{H}-\mathrm{NMR}\left(\mathrm{CDCl}_{3}, 600 \mathrm{MHz}\right)$ and ${ }^{13} \mathrm{C}-\mathrm{NMR}\left(\mathrm{CDCl}_{3}, 125 \mathrm{MHz}\right)$ data see Table 5 and Table 1 respectively. EI-MS m/z: $386\left([\mathrm{M}]^{+}\right)$. HRESIMS (pos.) $m / z: 387.1923\left([\mathrm{M}+\mathrm{H}]^{+}, \mathrm{C}_{21} \mathrm{H}_{27} \mathrm{~N}_{2} \mathrm{O}_{5}\right.$. calc. 387.1920).

Scholarisin VI (6). White amorphous powder. $[\alpha]_{D}^{23.3}:-38.5(c=0.35, \mathrm{MeOH}) . \mathrm{UV}\left(\mathrm{CHCl}_{3}\right) \lambda_{\max }(\log \varepsilon)$ 286 (3.30), 241 (3.81), 220 (3.31) nm. IR (KBr) $v_{\max }$ 3428, 1720, 1650, 1605, 1465, 1215, 1165, 1035 $\mathrm{cm}^{-1}$. ${ }^{1} \mathrm{H}-\mathrm{NMR}\left(\mathrm{CDCl}_{3}, 600 \mathrm{MHz}\right)$ and ${ }^{13} \mathrm{C}-\mathrm{NMR}\left(\mathrm{CDCl}_{3}, 125 \mathrm{MHz}\right)$ data see Table 5 and Table 1 respectively. EI-MS m/z: $382\left([\mathrm{M}]^{+}\right)$. HRESIMS (pos.) $m / z: 383.1974\left([\mathrm{M}+\mathrm{H}]^{+}, \mathrm{C}_{22} \mathrm{H}_{27} \mathrm{~N}_{2} \mathrm{O}_{4}\right.$. calc. 383.1971).

Scholarisin VII (7). White amorphous powder. $[\alpha]_{D}^{23.3}:-56.5(c=0.19, \mathrm{MeOH}) . \mathrm{UV}\left(\mathrm{CHCl}_{3}\right) \lambda_{\max }(\log \varepsilon)$ 285 (3.41), 239 (3.73), 218 (3.27), 195 (3.83) nm. IR (KBr) $v_{\max }$ 3448, 1735, 1635, 1455, 1442, 1166, $1015 \mathrm{~cm}^{-1} .{ }^{1} \mathrm{H}-\mathrm{NMR}\left(\mathrm{CDCl}_{3}, 600 \mathrm{MHz}\right)$ and ${ }^{13} \mathrm{C}-\mathrm{NMR}\left(\mathrm{CDCl}_{3}, 125 \mathrm{MHz}\right)$ data see Table 2 and Table 1 respectively. EI-MS m/z: $382\left([\mathrm{M}]^{+}\right)$. HRESIMS (pos.) m/z: $405.1787\left([\mathrm{M}+\mathrm{Na}]^{+}, \mathrm{C}_{22} \mathrm{H}_{26} \mathrm{~N}_{2} \mathrm{O}_{4} \mathrm{Na}\right.$. calc. 405.1790$)$. 
Table 5. ${ }^{1} \mathrm{H}-\mathrm{NMR}$ data of compounds $\mathbf{1}-\mathbf{7}$ in $\mathrm{CDCl}_{3}(\delta$ in ppm and $J$ in $\mathrm{Hz})$.

\begin{tabular}{|c|c|c|c|c|c|c|c|}
\hline No. & 1 & 2 & 3 & 4 & 5 & 6 & 7 \\
\hline$N_{1}-\mathrm{H}$ & $4.96(\mathrm{~s})$ & $4.98(\mathrm{~s})$ & $5.00(\mathrm{~s})$ & $5.04(\mathrm{~s})$ & $4.43(\mathrm{~s})$ & - & - \\
\hline 3 & - & - & - & $3.96(\mathrm{~m})$ & $3.36(\mathrm{~m})$ & $4.73(\mathrm{dd}, 14.0,4.0)$ & $4.48(\mathrm{dd}, 14.0,4.0)$ \\
\hline $5 \alpha$ & - & - & - & - & - & $2.18(\mathrm{~m})$ & - \\
\hline $5 \beta$ & $4.88(\mathrm{dd}, 4.2,3.6)$ & $4.86(\mathrm{~d}, 5.2)$ & $4.92(\mathrm{dd}, 4.0,3.6)$ & $5.28(\mathrm{dd}, 4.0,3.8)$ & $4.92(\mathrm{dd}, 7.2,5.6)$ & $2.32(\mathrm{~m})$ & $3.84(\mathrm{dd}, 4.0,3.8)$ \\
\hline $6 \alpha$ & $2.25(\mathrm{dd}, 13.6,4.2)$ & $2.26(\mathrm{~d}, 13.8)$ & $2.29(\mathrm{~d}, 14.0)$ & $2.75(\mathrm{dd}, 14.0,4.0)$ & $2.76(\mathrm{dd}, 14.4,5.6)$ & $2.06(\mathrm{~m})$ & $2.20(\mathrm{dd}, 14.0,4.0)$ \\
\hline $6 \beta$ & $3.41(\mathrm{dd}, 13.6,3.6)$ & $3.48(\mathrm{dd}, 13.8,5.2)$ & $3.52(\mathrm{dd}, 14.0,5.2)$ & $3.08(\mathrm{dd}, 14.0,3.8)$ & $3.10(\mathrm{dd}, 14.4,7.2)$ & $2.33(\mathrm{~m})$ & $3.75(\mathrm{dd}, 14.0,3.8)$ \\
\hline 9 & $7.31(\mathrm{dd}, 7.8,1.8)$ & $7.72(\mathrm{dd}, 8.2,2.0)$ & $7.76(\mathrm{dd}, 7.8,2.0)$ & $7.12(\mathrm{dd}, 8.2,1.8)$ & $7.14(\mathrm{dd}, 8.0,2.0)$ & $7.76(\mathrm{dd}, 7.8,2.0)$ & $7.79(\mathrm{dd}, 8.0,2.0)$ \\
\hline 10 & $6.84(\mathrm{dt}, 7.8,1.8)$ & $6.70(\mathrm{dt}, 8.2,2.0)$ & $6.82(\mathrm{dt}, 7.8,2.0)$ & $6.78(\mathrm{dt}, 8.2,1.8)$ & $6.77(\mathrm{dt}, 8.0,2.0)$ & $6.92(\mathrm{dt}, 7.8,2.0)$ & $7.39(\mathrm{dt}, 8.0,2.0)$ \\
\hline 11 & $7.08(\mathrm{dt}, 7.8,1.8)$ & $6.98(\mathrm{dt}, 8.2,2.0)$ & $7.14(\mathrm{dt}, 7.8,2.0)$ & $7.06(\mathrm{dt}, 8.2,1.8)$ & $7.10(\mathrm{dt}, 8.0,2.0)$ & $7.24(\mathrm{dt}, 7.8,2.0)$ & $7.14(\mathrm{dt}, 8.0,2.0)$ \\
\hline 12 & $6.68(\mathrm{dd}, 7.8,1.8)$ & $6.66(\mathrm{dd}, 8.2,2.0)$ & $6.78(\mathrm{dd}, 7.8,2.0)$ & $6.56(\mathrm{dd}, 8.2,1.8)$ & $6.66(\mathrm{dd}, 8.0,2.0)$ & $6.79(\mathrm{dd}, 7.8,2.0)$ & $7.32(\mathrm{dd}, 8.0,2.0)$ \\
\hline $14 \alpha$ & $2.26(\mathrm{dd}, 14.0,3.8)$ & $2.30(\mathrm{dd}, 14.0,3.8)$ & $2.33(\mathrm{dd}, 13.8,3.8)$ & $2.23(\mathrm{~m})$ & $2.25(\mathrm{~m})$ & $2.27(\mathrm{~m})$ & $2.88(\mathrm{~m})$ \\
\hline $14 \beta$ & $2.18(\mathrm{dd}, 14.0,4.0)$ & $2.27(\mathrm{dd}, 14.0,4.0)$ & $2.29(\mathrm{dd}, 13.8,4.0)$ & $1.91(\mathrm{~m})$ & $1.93(\mathrm{~m})$ & $2.24(\mathrm{~m})$ & $1.96(\mathrm{~m})$ \\
\hline 15 & $3.63(\mathrm{dd}, 4.0,3.8)$ & $3.69(\mathrm{dd}, 4.0,3.8)$ & $3.72(\mathrm{dd}, 4.0,3.8)$ & $2.95(\mathrm{dd}, 4.0,3.8)$ & $2.97(\mathrm{dd}, 4.0,3.8)$ & $3.62(\mathrm{dd}, 4.0,3.8)$ & $3.66(\mathrm{dd}, 4.0,3.8)$ \\
\hline 16 & - & - & - & $2.92(\mathrm{~d}, 4.8)$ & $2.59(\mathrm{~d}, 4.2)$ & - & - \\
\hline $17 \mathrm{a}$ & $8.52(\mathrm{~s})$ & $3.32(\mathrm{~d}, 13.8)$ & $3.87(\mathrm{~d}, 13.6)$ & - & - & $8.55(\mathrm{~s})$ & $3.68(\mathrm{~d}, 13.2)$ \\
\hline $17 b$ & - & $3.46(\mathrm{~d}, 13.8)$ & $4.01(\mathrm{~d}, 13.6)$ & - & - & - & $3.91(\mathrm{~d}, 13.2)$ \\
\hline 18 & $1.51(\mathrm{~d}, 7.0)$ & $1.55(\mathrm{~d}, 7.2)$ & $1.58(\mathrm{~d}, 7.0)$ & $1.40(\mathrm{~d}, 7.0)$ & $1.41(\mathrm{~d}, 6.8)$ & $1.83(\mathrm{~d}, 7.2)$ & $1.55(\mathrm{~d}, 7.0)$ \\
\hline 19 & $5.47(\mathrm{q}, 7.0)$ & $5.48(\mathrm{q}, 7.2)$ & $5.50(\mathrm{q}, 7.0)$ & $2.93(\mathrm{q}, 7.0)$ & $2.95(\mathrm{q}, 6.8)$ & $5.86(\mathrm{~d}, 7.2)$ & $5.54(\mathrm{~d}, 7.0)$ \\
\hline $21 \alpha$ & $3.85(\mathrm{~d}, 13.8)$ & $3.87(\mathrm{~d}, 14.2)$ & $3.89(\mathrm{~d}, 13.8)$ & $3.36(\mathrm{~d}, 14.0)$ & $3.39(\mathrm{~d}, 14.0)$ & $3.88(\mathrm{~d}, 13.8)$ & $4.07(\mathrm{~d}, 13.6)$ \\
\hline $21 \beta$ & $3.31(\mathrm{~d}, 13.8)$ & $3.33(\mathrm{~d}, 14.2)$ & $3.35(\mathrm{~d}, 13.8)$ & $3.08(\mathrm{~d}, 14.0)$ & $3.11(\mathrm{~d}, 14.0)$ & $3.35(\mathrm{~d}, 13.8)$ & $3.08(\mathrm{~d}, 13.6)$ \\
\hline $\mathrm{CO}_{2} \mathrm{CH}_{3}$ & $3.69(\mathrm{~s})$ & $3.78(\mathrm{~s})$ & $3.82(\mathrm{~s})$ & $3.70(\mathrm{~s})$ & $3.67(\mathrm{~s})$ & $3.80(\mathrm{~s})$ & $3.71(\mathrm{~s})$ \\
\hline$N_{1}-\mathrm{CH}_{3}$ & - & - & - & - & & $2.03(\mathrm{~s})$ & - \\
\hline $\mathrm{OCH}_{3}$ & $3.50(\mathrm{~s})$ & $3.52(\mathrm{~s})$ & $3.53(\mathrm{~s})$ & $3.10(\mathrm{~s})$ & $3.41(\mathrm{~s})$ & - & $3.25(\mathrm{~s})$ \\
\hline $\mathrm{COCH}_{3}$ & - & - & $1.53(\mathrm{~s})$ & - & & - & - \\
\hline
\end{tabular}




\subsection{Cytotoxicity Assay in Vitro}

The isolated compounds 1-10 were subjected to cytotoxic evaluation against A-549 cells (lung cancer), BGC-823 cells (human gastric carcinoma), HepG2 cells (human hepatocellular carcinoma), HL-60 (human myeloid leukemia), MCF-7 cells (human breast cancer), SMMC-7721 (hepatocellular carcinoma), and W480 (colon cancer) by employing the revised MTT method as described in the literature [31]. Doxorubicin was used as the positive control. All tumor cell lines were cultured on RPMI-1640 medium supplemented with $10 \%$ fetal bovine serum, $100 \mathrm{U} \mathrm{mL}^{-1}$ penicillin and $100 \mu \mathrm{g} / \mathrm{mL}$ streptomycin in $25 \mathrm{~cm}^{3}$ culture flasks at $37{ }^{\circ} \mathrm{C}$ in humidified atmosphere with $5 \% \mathrm{CO}_{2}$. For the cytotoxicity tests, cells in exponential growth stage were harvested from culture by trypsin digestion and centrifuging at $180 \times g$ for $3 \mathrm{~min}$, then resuspended in fresh medium at a cell density of $5 \times 10^{4}$ cells per $\mathrm{mL}$. The cell suspension was dispensed into a 96-well microplate at $100 \mu \mathrm{L}$ per well, and incubated in humidified atmosphere with $5 \% \mathrm{CO}_{2}$ at $37^{\circ} \mathrm{C}$ for $24 \mathrm{~h}$, and then treated with the compounds at various concentrations $(0,1,10,100 \mu \mathrm{M})$. After $48 \mathrm{~h}$ of treatment, $50 \mu \mathrm{L}$ of $1 \mathrm{mg} / \mathrm{mL}$ MTT solution was added to each well, and further incubated for $4 \mathrm{~h}$. The cells in each well were then solubilized with DMSO $(100 \mu \mathrm{L}$ for each well) and the optical density (OD) was recorded at $570 \mathrm{~nm}$. All drug doses were tested in triplicate and the $\mathrm{IC}_{50}$ values were derived from the mean $\mathrm{OD}$ values of the triplicate tests versus drug concentration curves. The $50 \%$ inhibition concentration ( $\mathrm{IC}_{50}$ value) was determined by curve fitting and was used as criteria to judge the cytotoxicity (active: $\mathrm{IC}_{50} \leq 20 \mu \mathrm{M}$; moderately active: $20 \mu \mathrm{M}<\mathrm{IC}_{50} \leq 80 \mu \mathrm{M}$; not active: $\mathrm{IC}_{50}>80 \mu \mathrm{M}$ ). All cell lines were purchased from Cell Bank of Shanghai Institute of Biochemistry \& Cell Biology, Chinese Academy of Sciences. Other reagents were purchased from Shanghai Sangon Biological Engineering Technology \& Services Co., Ltd. (Shanghai, China).

\subsection{Anti-Inflammatory Assay in Vitro}

The anti-inflammatory activities were determined according to a literature method with minor modifications [32]. The reaction system was incubated at $25{ }^{\circ} \mathrm{C}$ for $5 \mathrm{~min}$, by sequential addition of the buffer, heme, test compounds, and Cox-1 or Cox- 2 into the system followed by mixing with TMPD and arachidonic acid. The absorbance value was recorded at a wavelength of $590 \mathrm{~nm}$ after another $15 \mathrm{~min}$ of incubation at $25^{\circ} \mathrm{C}$. SC-560 and NS-398 were used as positive controls, which gave the inhibition of Cox-1 (63.20\%) and Cox-2 (97.13\%) respectively (Table 3). All cell lines were purchased from the Cell Bank of Shanghai Institute of Biochemistry \& Cell Biology, Chinese Academy of Sciences. (Shanghai, China).

\subsection{Antifungal Activity Bioassay}

All compounds (purity $>90 \%$ ) were screened for their antifungal activity in vitro using the disk-diffusion method as described in the literature with minor modifications [33]. Strains including five species of fungi [Gibberella pulicaris (KZN 4207), Alternaria alternata (TX-8025), Colletotrichum nicotianae (SACC-1922), Phytophthora capsici (KACC-40157), Gonatopyricularia amomi (MB-9671)] were used. Nystatin were used as positive controls for antifungal activity. A disk containing only DMSO was used as the negative control. Agar medium was used in the antifungal activity. To each agar plate, an inoculum containing $10^{7}$ bacteria $/ \mathrm{mL}$ or a 0.5 optical density of the 
McFarland Scale was incorporated. The plates were solidified and sterile filter paper disks (6-mm diameter) were done on each one. Solution of each compound (5 mM) in DMSO, antifungal agents (nystatin $10 \mu \mathrm{M} / \mathrm{mL}$ ), and control vehicles (DMSO) were added into too. The plates were aerobically incubated at $37^{\circ} \mathrm{C}$ for the five species of fungi during $24 \mathrm{~h}$. The diameter of the inhibition zone was measured for testing of antifungal activities. Experiments were performed in triplicate, and the results are presented as the mean values of the diameters of the inhibitory zones from three runs. The MIC values of the most active compounds, in the previous experiment, were determined using the dilution method in 96-hole plates. The diameters of the inhibitory zones and the MIC value were used as criteria to judge the antimicrobial activity (active: the diameters of the inhibitory zones $\geq 16 \mathrm{~mm}, \mathrm{MIC} \leq 5 \mathrm{mM}$; moderately active: the diameters of the inhibitory zones are visible, MIC $>5 \mathrm{mM}$; not active: the diameters of the inhibitory zones are invisible). All fungal were purchased from the Shanghai Institute of Biochemistry \& Cell Biology, Chinese Academy of Sciences (Shanghai, China).

\section{Conclusions}

A chemical investigation of the $70 \% \mathrm{EtOH}$ extract of the dried leaves of $A$. scholaris resulted in the isolation of seven new monoterpenoid indole alkaloids: scholarisin I-VII (1-7), and three known compounds: $(3 R, 5 S, 7 R, 15 R, 16 R, 19 E)$-scholarisine $\mathrm{F}(\mathbf{8})$, 3-epi-dihydrocorymine (9), and (E)-16formyl-5 $\alpha$-methoxystrictamine (10). All the isolated compounds 1-10 were evaluated for their cytotoxic activities against seven tumor cell lines and alkaloids $\mathbf{1 ,} \mathbf{6}$ and $\mathbf{1 0}$ possessed significant cytotoxicities against all the tested tumor cell lines with low $\mathrm{IC}_{50}$ values $(<30 \mu \mathrm{M})$. In screening in vitro of cytotoxic activities of all the alkaloids anti-inflammatory properties against Cox-1 and Cox-2, 1, 6 and 10 showed selective inhibition of Cox-2 (>90\%) comparable with the standard drug NS-398. Additionally, 1, 2, 3 and $\mathbf{8}$ had antifungal activity against two fungal spp. (G. pulicaris and C. nicotianae).

\section{Conflict of Interest}

The authors declare no conflict of interest.

\section{References}

1. Narine, L.L.; Maxwell, A.R. Monoterpenoid indole alkaloids from Palicourea crocea. Phytochem. Lett. 2009, 2, 34-36.

2. Tan, S.J.; Lim, K.H.; Subramaniam, G.; Kam, T.S. Macroline-sarpagine and macroline-pleiocarpamine bisindole alkaloids from Alstonia angustifolia. Phytochemistry 2012, doi:10.1016/j.phytochem.2012.08.016.

3. Ku, W.F.; Tan, S.J.; Low, Y.Y.; Komiyama, K.; Kam, T.S. Angustilobine and andranginine type indole alkaloids and an uleine-secovallesamine bisindole alkaloid from Alstonia angustiloba. Phytochemistry 2011, 72, 2212-2218.

4. Li, P.T.; Leeuwenberg, A.J.M.; Middleton, D.J. Flora of China; Science Press: Beijing, China and Missouri Botanical Garden, St. Louis, MO, USA, 1995; Volume 16, p. 154.

5. Channa, S.; Dar, A.; Atta-ur-Rahman, A.S. Evaluation of Alstonia scholaris leaves for broncho-vasodilatory activity. J. Ethnopharmacol. 2005, 97, 469-476. 
6. Sexton, J.E. Alkaloids of the Alstonia Species. In The Alkaloids: Chemistry and Physiology; Manske, R.H.F., Ed.; Academic Press: New York, NY, USA, 1965; Volume 8, pp. 159-202.

7. Gandhi, M.; Vinayak, V.K.J. Preliminary evaluation of extracts of Alstonia scholaris bark for in vivo antimalarial activity in mice. J. Ethnopharmacol. 1990, 29, 51-57.

8. Wright, C.W.; Allen, D.; Phillipson, J.D.; Kirby, G.C.; Warhurst, D.C.; Massiot, G.; Le Men-Olivier, L. Alstonia species: Are they effective in malaria treatment? J. Ethnopharmacol. 1993, 40, 41-45.

9. Leaman, D.J.; Arnason, J.T.; Yusuf, R.; Roemantyo, H.S.; Soedjito, H.; Angerhofer, C.K.; Pezzuto, J.M. Malaria remedies of the Kenyah of the Apo Kayan, East Kalimantan, Indonesian Borneo: A quantitative assessment of local consensus as an indicator of biological efficacy. J. Ethnopharmacol. 1995, 49, 1-16.

10. Kam, T.S.; Nyedh, K.T.; Sim, K.M.; Yoganathan, K. Alkaloids from Alstonia Scholaris. Phytochemistry 1997, 45, 1303-1305.

11. Lim, S.H.; Low, Y.Y.; Tan, S.J.; Lim, K.H.; Thomas, N.F.; Kam, T.S. Perhentidines A-C: Macroline-macroline bisindoles from Alstonia and the absolute configuration of perhentinine and macralstonine. J. Nat. Prod. 2012, 75, 942-950.

12. Lim, S.H.; Tan, S.J.; Low, Y.Y.; Kam, T.S. Lumutinines A-D, linearly fused macroline-macroline and macroline-sarpagine bisindoles from Alstonia macrophylla. J. Nat. Prod. 2011, 74, 2556-2562.

13. Tan, S.J.; Choo, Y.M.; Thomas, N.F.; Robinson, W.T.; Komiyama, K.; Kam, T.S. Unusual indole alkaloid-pyrrole, -pyrone, and -carbamic acid adducts from Alstonia angustifolia. Tetrahedron 2010, 66, 7799-7806.

14. Arai, H.; Hirasawa, Y.; Rahman, A.; Kusumawati, I.; Zaini, N.C.; Sato, S.; Aoyama, C.; Takeo, J.; Morita, H. Alstiphyllanines E-H, picraline and ajmaline-type alkaloids from Alstonia macrophylla inhibiting sodium glucose cotransporter. Bioorg. Med. Chem. 2010, 18, 2152-2158.

15. Hirasawa, Y.; Arai, H.; Zaima, K.; Oktarina, R.; Rahman, A.; Ekasari, W.; Widyawaruyanti, A.; Indrayanto, G.; Zaini, N.C.; Morita, H. Alstiphyllanines A-D, Indole alkaloids from Alstonia macrophylla. J. Nat. Prod. 2009, 72, 304-307.

16. Hirasawa, Y.; Miyama, S.; Kawahara, N.; Goda, Y.; Rahman, A.; Ekasari, W.; Widyawaruyanti, A.; Indrayanto, G.; Zaini, N.C.; Morita, H. Indole alkaloids from the leaves of Alstonia scholaris. Heterocycles 2009, 79, 1107-1112.

17. Kam, T.S.; Choo, Y.M. New indole alkaloids from Alstonia macrophylla. J. Nat. Prod. 2004, 67, $547-552$.

18. Koyama, K.; Hirasawa, Y.; Hosoya, T.; Hoe, T.C.; Chan, K.L.; Morita, H. Alpneumines A-H, new anti-melanogenic indole alkaloids from Alstonia pneumatophora. Bioorg. Med. Chem. 2010, 18, 4415-4421.

19. Koyama, K.; Hirasawa, Y.; Nugroho, A.E.; Hosoya, T.; Hoe, T.C.; Chan, K.L.; Morita, H. Alsmaphorazines A and B, novel indole alkaloids from Alstonia pneumatophora. Org. Lett. 2010, $12,4188-4191$.

20. Macabeo, A.P.G.; Krohn, K.; Gehle, D.; Read, R.W.; Brophy, J.J.; Cordell, G.A.; Franzblau, S.G.; Aguinaldo, A.M. Indole alkaloids from the leaves of Philippine Alstonia scholaris. Phytochemistry 2005, 66, 1158-1162. 
21. Salim, A.A.; Garson, M.J.; Craikc, David J. New Indole Alkaloids from the Bark of Alstonia scholaris. J. Nat. Prod. 2004, 67, 1591-1594.

22. Tan, S.J.; Low, Y.Y.; Choo, Y.M.; Abdullah, Z.; Etoh, T.; Hayashi, M.; Komiyama, K.; Kam, T.S. Strychnan and secoangustilobine A type alkaloids from Alstonia spatulata. Revision of the C-20 configuration of scholaricine. J. Nat. Prod. 2010, 73, 1891-1897.

23. Hutchinson, C.R. Tetrahedron report number 105: Camptothecin: Chemistry, biogenesis and medicinal chemistry. Tetrahedron 1981, 37, 1047-1065.

24. Kam, T.S.; Choo, Y.M.; Komiyama, K. Unusual spirocyclic macroline alkaloids, nitrogenous derivatives, and a cytotoxic bisindole from Alstonia. Tetrahedron 2004, 60, 3957-3966.

25. Kam, T.S.; Tan, S.J.; Ng, S.W.; Komiyama, K. Bipleiophylline, an unprecedented cytotoxic bisindole alkaloid constituted from the bridging of two indole moieties by an aromatic spacer unit. Org. Lett. 2008, 10, 3749-3752.

26. Jagetia, G.C.; Baliga, M.S. Evaluation of anticancer activity of the alkaloid fraction of Alstonia scholaris (Sapthaparna) in vitro and in vivo. Phytother. Res. 2006, 20, 103-109.

27. Khan, M.R.; Omoloso, A.D.; Kihara, M. Antibacterial activity of Alstonia scholaris and Leea tetramera. Fitoterapia 2003, 74, 736-740.

28. Feng, T.; Cai, X.H.; Zhao, P.J.; Du, Z.Z.; Li, W.Q.; Luo, X.D. Monoterpenoid indole alkaloids from the bark of Alstonia scholaris. Planta. Med. 2009, 75, 1537-1541.

29. Zhou, H.; He, H.P.; Luo, X.D.; Wang, Y.H.; Yang, X.W.; Di,Y.T.; Hao, X.J. Three New Indole Alkaloids from the Leaves of Alstonia scholaris. Helv. Chim. Acta. 2005, 88, 2508-2512.

30. Lim, K.H.; Hiraku, O.; Komiyama, K.; Kam T.S. Jerantinines A-G, cytotoxic Aspidosperma alkaloids from Tabernaemontana corymbosa. J. Nat. Prod. 2008, 71, 1591-1594.

31. Yu, J.O.; Liao, Z.X.; Lei, J.C.; Hu, X.M. Antioxidant and cytotoxic activities of various fractions of ethanol extract of Dianthus superbus. Food. Chem. 2007, 104, 1215-1219.

32. Duan, W.G.; Zhang, L.Y. Prostaglandins, Cyclooxygenase inhibitors not inhibit resting lung cancer A549 cell proliferation. Prostaglandins Leukot. Essent. Fatty. Acids. 2006, 74, 317-321.

33. Espine-Ingroff, A.; White, T.; Pfaller, M.A. Manual of Clinical Microbiology. 7th ed.; American Society for Microbiology: Washington, DC, USA, 1999; pp. 1640-1652.

Sample Availability: Samples of the compounds 1-10 are available from the authors.

(C) 2013 by the authors; licensee MDPI, Basel, Switzerland. This article is an open access article distributed under the terms and conditions of the Creative Commons Attribution license (http://creativecommons.org/licenses/by/3.0/). 